\title{
Abdominal Vascular Injuries Due to Missile Wounds
}

\author{
Ateşli Silahlara Bağlı Batın İçi Damar Yaralanmaları \\ Hakan Bingöl \\ Clinic of Cardiovascular Surgery, Başkent University Medical Research Center, Konya, Turkey
}

\begin{abstract}
Objective: Although abdominal vascular injuries due to missile bullets are less common compared to other injuries, they are of great importance because of the high mortality rate. There are many factors affecting the mortality rate such as; transportation time, type of injury, visceral organ damages, amount of blood loss and surgical experience of the medical and surgical team. The aim of this study is to assess the mortality rate of abdominal vascular injury caused by the bullets of rifles when visceral organs injury is associated with vascular injury.

Methods: Between 1993-2008, registries in surgery department of the hospitals affiliated to Başkent University were scanned and 27 abdominal vascular injuries of a total of 212 abdominal wound cases were detected. The mean age was $24 \pm 12$ years ( 22 men and 5 women). Ages ranged from 12 to 58 years. The cause of injury was a mine explosion and firearm in one patient, and firearms in the others. All cases had vascular injuries. 16 cases had major venous injuries, 6 had major arterial injuries and the remaining 5 cases have major arterial and venous injuries.

Results: Fifty-four abdominal organ injuries were determined. Twenty-seven of these 54 patients had abdominal vascular injuries. Only one patient's systolic blood pressure was higher than $50 \mathrm{mmHg}$ in the preoperative period. The remaining patients had lower systolic blood pressures. In addition, the blood pressure of ten patients could not be determined during admission to the emergency department. Major venous injuries had the worst preoperative hemodynamics. Twenty-three of 54 patients had liver injury (42.59\%), stomach injury in 14 patients (25.92\%), right kidney injury in 7 patients (12.96), left kidney injury in 5 patients (9.25\%) and multiple organ injuries in 2 patients (3.7\%). Eight patients underwent vascular ligation, primary repair was done in 12 patients and graft interposition was done in 7 patients. However, 5 cases died before surgical intervention. Out of 5 deaths, one patient died because of sepsis (postoperative $2^{\text {nd }}$ day), one patient died from VCl laceration, sepsis occurred in one, 1 died from renal venous trauma, 1 from vena porta injury and one from cerebral hemorrhage associated with abdominal vascular injury. The management of inferior caval vein injuries, which are responsible for $60 \%$ of all deaths, were the most challenging.
\end{abstract}

Conclusion: Vascular traumas within the abdominal area are fatal clinical conditions and complications. Abdominal aortic injuries have a higher fatality rate than venous injuries. Outcomes in abdominal vascular injuries due to missile wounds still depend on transportation time and coincident inferior caval vein and abdominal organ injuries. (JAREM 2014; 1: 25-7)

Key Words: Abdominal, vascular injuries, missile wounds

\section{ÖZET}

Amaç: Bu çalışmanın amacı ateşli silahlara bağlı kurşun yaralanmaları sonucunda gelişen karın içi damar yaralanmalarının eşlik ettiği organ yaralanmalarına bağlı mortalite oranlarını değerlendirmektir.

Yöntemler: 1993-2008 yılları arasında batına isabet eden kurşun yaralanmalı toplam 212 hasta Başkent Üniversitesi'ne bağlı hastanelerin cerrahi departmanlarına müracaat etmiş olup bu hastaların 27'sinde batın içi damar yaralanması mevcuttu. Toplam 27 hastanın (22 erkek ve 5 bayan) ortalama yaşları 24 \pm 12 idi (12-58 yaş). Bir hastada yaralanma mayın patlaması ve ateşli silah yaralanması sonucu oluşmuştu, diğer hastalarda yaralanma ateşli silah yaralanmasına bağlı idi. Hastaların hepsinde ateşli silah yaralanmasına bağlı damar hasarı mevcuttu. Vakaların 16 sında büyük ven yaralanması, 6'sında büyük arter yaralanması ve diğer 5 vakada ise hem büyük arter hemde büyük ven yaralanması mevcuttu.

Bulgular: İkiyüz on iki hastanın 54 ünde batın içi organ yaralanması mevcuttu. Elli dört hastanın 27 sinde organ yaralanmasına ilave olarak damar yaralanması vardı. Hastaların 23'ünde karaciğer yaralanması (\%42,59), 14'ünde mide yaralanması (\%25,92), 7'sinde sağ böbrek (\%12,96), 5'inde sol böbrek (\%9,25), 2'sinde multiple organ (\%3,7) yaralanması vardı. Sekiz hastada damar ligasyonu, 12'sinde primer tamir operasyonu, 7'sinde ise greft interpozisyonu uygulandı. Cerrahi girişimi takiben 5 hasta hayatını kaybetti. Beş hastanın 1 tanesi sepsisden (Postop. 2. gün) ölürken geri kalan 4 hasta aşırı kanamaya bağlı olarak kaybedildi. Ölümlerin \%60'ına neden olan vena kava inferior yaralanmaları en çok dikkat edilmesi gereken yaralanmalardır.

Sonuç: Abdominal bölgede oluşan damar yaralanmaları komplikasyonlarla ve ölümcül olaylarla sonuçlanabilir. Abdominal aort yaralanmaları venöz yaralanmalara göre daha yüksek mortaliteye sahiptir. Abdominal damar yaralanmalarında sonuçlar hala hastanın nakil süresine ilave vena cava inferior ve ilave organ yaralanmasına bağlı olarak değişmektedir. (JAREM 2014; 1: 25-7)

Anahtar Sözcükler: Batın, damar yaralanmaları, ateşli silah yaralanmaları

\section{INTRODUCTION}

Although abdominal vascular injuries due to missile bullets are less common compared to other injuries, they have a high mortality rate (1-5). Due to the difficulties in managing the treatment of such events, most surgeons fear facing a missile wound causing vascular injury in the abdomen (3-7). They frequently occur with serious associated injuries (2). Abdominal vascular injuries are serious clinical problems in emergency, general and vascular surgery departments. There are many factors affecting mortality rates such as; transportation time, type of injury, visceral organ damage, amount of blood loss and surgical experience of the medical and surgical teams (1-3). The success in management depends on the control of bleeding following rapid exposure and establishing revascularization using appropriate surgical techniques (4-8). This article will be focused on the factors affect- 
Table 1. Major venous injury

\begin{tabular}{|l|l|c|}
\hline \multirow{2}{*}{ Major venous injuries } & Place of injury & Number of cases \\
\hline \multirow{2}{*}{ Inferior caval vein } & 7 \\
\cline { 2 - 3 } & Portal vein & 3 \\
\cline { 2 - 3 } & External iliac vein & 3 \\
\cline { 2 - 3 } & Renal vein & 2 \\
\cline { 2 - 3 } & Splenic vein & 1 \\
\hline \multirow{2}{*}{} & Total & 16 \\
\hline
\end{tabular}

Table 2. Major arterial injury

\begin{tabular}{|l|c|}
\hline Place of injury & Number of cases \\
\hline External iliac artery & 2 \\
\hline Internal iliac artery & 2 \\
\hline Splenic artery & 1 \\
\hline Gastroduodenal artery & 1 \\
\hline Total & 6 \\
\hline
\end{tabular}

ing the outcomes of abdominal vascular injuries and its coincidence with visceral organ damage.

\section{METHODS}

We retrospectively investigated the three Surgical Hospital registries, between 1993 and 2008. 27 of a total of 212 abdominally injured patients had vascular injuries, were inpatients and underwent urgent laparotomy. The mean age of the patients was $24 \pm 12$ year (22 men and 5 women). Ages ranged between 12 and $58 y e a r s$. The cause of injury was a mine explosion in one patient, and firearms in the others. In our series, the average time between the onset of trauma and arrival to the emergency room is $37 \pm 16$ minutes. If the sources are available, patient care consists of endotracheal intubation, intravenous fluid administration and compression to control bleeding in the field. With missile wounds, nearly all patients were transported to the emergency department by helicopter or ambulance in order to avoid time wasting. In the emergency room, patients were evaluated by a group of surgeons including a general surgeon, a thoracic surgeon and a cardiovascular surgeon. According to their hemodynamic status, all patients were taken directly to the operating room without detailed examination. Soon after, they underwent laparotomy to explore bleeding vessels and organ dysfunction.

\section{RESULTS}

Twenty-seven vascular injury cases were recorded. 16 patients had major venous injuries, 6 had major arterial injuries, and the remaining 5 cases had both arterial and venous injuries (Table 1-3). Associated injuries were observed mostly over the stomach and, to a lesser extent, over the duodenum and liver. Table 4 shows the associated visceral organ injuries. Only one patient's systolic blood pressure was higher than $50 \mathrm{mmHg}$ in the preoperative period. The remaining patients had a systolic blood pressure lower than $50 \mathrm{mmHg}$. In addition, the blood pressure of ten patients could not be determined during admission to the emergency department. Major venous injuries had the worst preoperative hemodynamics. Operative management concern-

\section{Table 3. Major arterial and venous injury}

\begin{tabular}{|c|c|c|}
\hline & Place of injury & Number of cases \\
\hline \multirow{6}{*}{$\begin{array}{l}\text { Major arterial and } \\
\text { venous injuries }\end{array}$} & a.v. ${ }^{*}$ renalis & 1 \\
\hline & a.v. iliac externa & 1 \\
\hline & a.v. colica media & 1 \\
\hline & a.v. splenica & 1 \\
\hline & a.v. mesenterica superior & 1 \\
\hline & Total & 5 \\
\hline *a.v.: artery and vein & & \\
\hline
\end{tabular}

Table 4. Associated visceral injuries (Primarily involved)

\begin{tabular}{|l|c|}
\hline Visceral organ injury & The number of cases \\
\hline Stomach & 9 \\
\hline Duodenum & 5 \\
\hline Jejunum & 2 \\
\hline Ileum & 2 \\
\hline Colon & 10 \\
\hline Rectum & 1 \\
\hline Gall bladder & 1 \\
\hline Choledochus & 1 \\
\hline Liver & 7 \\
\hline Pancreas & 4 \\
\hline Ureter & 2 \\
\hline Urinary bladder & 2 \\
\hline Spleen & 6 \\
\hline Kidney & 2 \\
\hline
\end{tabular}

ing vascular injuries included vessel ligation in 8 case, primary repair in 12 cases, and saphenous vein interposition in 7 cases. Five perioperative deaths occurred as shown in Table 5. One of the patients died due to $\mathrm{VCl}$ laceration, 1 of renal venous trauma, 1 ofvena porta injury perioperatively and one of cerebral hemorrhage associated with abdominal vascular injury and sepsis in the remaining as shown in Table 6.

\section{DISCUSSION}

During World War I, missile wounds had trained surgeons how to treat patients efficiently and rapidly The time interval between injury and intervention decreased from 12.5 hours in World War II to 1.6 hours in the Vietnam War (1). Arrival in time and faster transport allows patients to reach emergency departments alive. Therefore, mortality depends not only on time lost in transportation but also on the surgical team's knowledge and performance.

In case of major abdominal injury, time is a precious treasure not to be wasted by the patient's clinical evaluation. Surgeons need an exact management algorithm for diagnosis. Indeed, in these types of injuries, the presence of shock and bullet entrance shows that the diagnosis can be properly made following laparotomy. A long midline incision is the quickest access and gives us most extensive exposure. The main problem is when some patients do not appear to be so critically injured. A more complete evaluation and preparation should be made. Although the hos- 
Table 5. Operative procedures for vascular injury

\begin{tabular}{|l|c|}
\hline Surgical procedures & Number \\
\hline Primary repair & 8 \\
\hline Vessel ligation & 12 \\
\hline Repaired by using graft (saphenous vein) & 7 \\
\hline Total & 27 \\
\hline
\end{tabular}

pitals near the skirmish region may not be sufficiently qualified for further evaluation or intervention; if possible, patients should be stabilized before being transported to the next step. In case of any signs of deterioration in the patient's hemodynamics during stabilization, surgical intervention should be implemented as soon as possible (6-8). In our patients, because of the hemodynamic disturbance, laparotomy was inevitable and vascular injury diagnosis was made only during operation.

All penetrating abdominal traumas resulting in retroperitoneal hematomas should be explored in order to pinpoint the location of major vascular injury. Ignorance of this concept may lead us to confront more complicated hemodynamics, such as rupture of the hematoma or massive blood loss during follow up. Any findings of a palpable thrill with a hematoma are an indication of an AV fistula (9). We have not seen any postoperative AV fistulas in our patients.

In our series, most of the deaths from great veins that occurred prior to laparotomy and just after anesthetic induction, which indicates that, after anesthesia, perivascular connective tissues and abdominal wall which help in restricting the hematoma become flaccid and cause the patient to bleed to death. We recommend that all preparations for exploration should be finished before anesthesia has begun.

Because we believe that the synthetic grafts are more vulnerable to graft infection, the injured vessels were mostly ligated or primarily restored in our patient group. After arterial reconstruction we followed the distal flow by pulse examination. However, some authors recommend evaluation with postoperative arteriography or venography (8-10). Vascular traumas within the abdominal area are fatal clinical conditions. Abdominal aortic injuries are more fatal than venous injuries, the rate ranging between $21-74 \%$ (2-5). Although better anesthetic and operative techniques for critically ill patients have been developed, mortality rates for abdominal vascular injuries are still 54-70\% (10-16).

In conclusion, the mortality and morbidity of the patients depend on various factors, including the location and mechanism of injury, presence of shock at admission, associated major vascular and visceral organ injuries, delay in treatment, surgeon's knowledge and experience, and adequate postoperative care.

Ethics Committee Approval: Ethics committee approval was not received due to the retrospective nature of the study.

Informed Consent: Informed consent was not received due to the retrospective nature of the study.

Peer-review: Externally peer-reviewed.

Conflict of Interest: No conflict of interest was declared by the author.

Financial Disclosure: The authors declared that this study has received no financial support.

\section{Table 6. Injured vessels causing mortality}

\begin{tabular}{|l|c|}
\hline Vessel injury & Number \\
\hline VCl & 1 \\
\hline Renal Vein & 1 \\
\hline Mesenteric Vessels & 1 \\
\hline Portal vein & 1 \\
\hline Cerebral Hemorrhage & 1 \\
\hline Total & 5 \\
\hline
\end{tabular}

Etik Komite Onayı: Çalışmanın retrospektif tasarımından dolayı etik komite onayı alınmamıştır.

Hasta Onamı: Çalışmanın retrospektif tasarımından dolayı hasta onamı alınmamıştır.

Hakem Değerlendirmesi: Dış bağımsız.

Çıkar Çatışması: Yazar çıkar çatışması bildirmemiştir.

Finansal Destek: Yazar bu çalışma için finansal destek almadıklarını beyan etmiştir.

\section{REFERENCES}

1. Billy LJ, Amato JJ, Rich NM. Aortic injuries in Vietnam. Surgery 1971; 70: 385.

2. Lim RC, Trunkey DD, Blaisdell FW. Acute abdominal aortic injury: an analysis of operative and postoperative management. Arch Surg 1974; 109: 706-11. [CrossRef]

3. Burns GR, Sherman RT. Trauma of the abdominal aorta and inferior vena cava. Am Surg 1972; 38: 303-6.

4. Turpin I, Slate D, Swhwartz A. Injuries to the vena cava and their management. Am J Surg 1977; 134: 25-32. [CrossRef]

5. Allen TW, Reull GJ, Morton JR, Beall AC Jr. Surgical management of aortic trauma. J Trauma 1972; 12: 862-8. [CrossRef]

6. Bole PV, Purdy RT, Munda RT, Moallem S, Devanesan J, Clauss RH. Civillian arterial injuries. Ann Surg 1976; 183: 13-23. [CrossRef]

7. Burns GR, Sherman RT. Trauma of the abdominal aorta and inferior vena cava. Am Surg 1972; 38: 303-6.

8. Mattox KL, Whisennand HH, Espada R, Beall Jr AC. Management of acute combined injuries to the aorta and inferior vena cava. Am J Surg 1975; 130: 720-4. [CrossRef]

9. Bole PV, Cortes LE, Munda RT, Devanesan J, Purdy RT. Repair of a false aneurysm of the abdominal aorta. J Trauma 1975; 15: 255-9. [CrossRef]

10. Fox CJ, Patel B, Clouse WD. Update on wartime vascular injury. Perspect Vasc Surg Endovasc Ther 2011; 23: 13-25. [CrossRef]

11. Schrager JJ, Branson RD, Johannigman JA. Lessons from the tip of the spear: medical advancements from Iraq and Afghanistan. Respir Care 2012; 57: 1305-13. [CrossRef]

12. Mosquera VX, Marini M, Cao I, Gulías D, Muñiz J, Herrera-Noreña $\mathrm{JM}$, et al. Traumatic aortic injuries associated with major visceral vascular injuries in major blunt trauma patients. World J Surg 2012; 36: 1571-80. [CrossRef]

13. Bhagvan $\mathrm{S}, \mathrm{Ng} A$, Civil I. Penetrating thoraco-abdominal injuries: the Auckland City Hospital experience. ANZ J Surg 2011; 81: 595-600. [CrossRef]

14. Chovanes J, Cannon JW, Nunez TC. The evolution of damage control surgery. Surg Clin North Am 2012; 92: 859-75. [CrossRef]

15. Jaha L, Andreevska T, Rudari H, Ademi B, Ismaili-Jaha V. A decade of civilian vascular trauma in Kosovo. World J Emerg Surg 2012; 7: 24. [CrossRef]

16. Sorrentino TA, Moore EE, Wohlauer MV, Biffl WL, Pieracci FM, Johnson $\mathrm{JL}$, et al. Effect of damage control surgery on major abdominal vascular trauma. J Surg Res 2012; 177: 320-5. [CrossRef] 